\title{
TESTING ENVIRONMENTAL KUZNETS CURVE HYPOTHESIS: THE ROLE OF ENTERPRISE'S SUSTAINABILITY AND OTHER FACTORS ON GHG IN EUROPEAN COUNTRIES
}

\author{
Giedrė LAPINSKIENÉ ${ }^{1}$, Kęstutis PELECKIS ${ }^{2}$, Zlatko NEDELKO ${ }^{3}$ \\ 1,2Vilnius Gediminas Technical University, Saulètekio al. 11, LT-10223 Vilnius, Lithuania \\ ${ }^{3}$ University of Maribor, Faculty of Economics and Business, \\ Razlagova 14, 2000 Maribor, Slovenia \\ Emails: ${ }^{1}$ giedre.lapinskiene@vgtu.lt (corresponding author); \\ ${ }^{2}$ kestutis.peleckis@vgtu.lt; ${ }^{3}$ zlatko.nedelko@um.si
}

Received 30 May 2016; accepted 13 October 2016

\begin{abstract}
The paper analyses the environmental Kuznets curve relationship between greenhouse gases and chosen indicators of economic development based on the panel data of 20 countries of the EU in the period 2006-2013. Besides the typical variables, such as the share of a particular polluting industry, environmental taxes, energy taxes, research and development, the dummy variable of the crises and enterprise's sustainability score were also included in the model. The fixed effect panel model was used as a framework for the analysis. The original contribution of this paper is that the factor referring to the enterprises' sustainability was empirically tested in the expanded model. Higher energy taxes, research and development and the number of sustainable enterprises decrease the level of greenhouse gases. The size of agriculture, production and construction has a positive sign, which means that a higher value of the indicator is associated with a higher level of greenhouse gases. This implies that the analysed set of factors can be applied to adjust the trend in the region and might be useful for the climate change policy adjustment.
\end{abstract}

Keywords: greenhouse gases, economic development, gross domestic product, environmental Kuznets curve, sustainable enterprises, European Union countries.

JEL Classification: Q56, C33.

\section{Introduction}

Over the period of about 150 years, which began with the industrial revolution, great amounts of carbon dioxide and other gases, producing the so called greenhouse effect, were released into the atmosphere. It is assumed that greenhouse gases (GHG) is affected by various factors of economic activity that are mostly referred to the gross domestic product (GDP) terms. Generally, the rising level of GHG is affected by unsustainable agriculture, excessive fuels combustion for energy, heat, transport and business as well as huge amount of waste and deforestation trends. It is the consequence of growing population and its demand. Hence, economic growth leads to higher output and thus to higher pollution ceteris paribus. 
In the scientific sphere the question of how a continuous economic growth affects the level of GHG is very important and has been analysed by many scientists. The authors of some studies demonstrated the necessity of slowing down economic growth and moving to the steady state economy (Meadows et al. 1972, 2004; Randers 2012). The large group of studies analysing the relationship between the economic growth and the environment change are performed under the framework of environmental Kuznets curve (EKC). The EKC indicates that at the early stages of economic growth, pollution increases with the growing use of resources, but when a certain level of income per capita is reached, the trend reverses so that, at a higher development stage, further economic growth leads to the improvement of the environment. Under the EKC concept the relationship between carbon dioxide and economic growth was firstly analysed by the World Bank, and the results of the research showed the increasing trends (Shafik, Bandyopadhyay 1992). Till our days many studies were performed using $\mathrm{CO}_{2}$ or GHG. Some studies support the EKC hypothesis, while others find a monotonically rising trend. Researchers determined that other social and political factors were important and used this framework to test the significance of the chosen indicators. The large group of researchers estimated economic factors that are related to the energetic sector from fuel types and prices, energy usage and energy efficiency (Fosten et al. 2012; Boluk, Mert 2014; Azam, Khan 2016; Rodríguez et al. 2016; Alam et al. 2016). Others highlighted the sectorial structure (Lapinskienè et al. 2013, 2014; Alam et al. 2016), trade openness (Fujii, Managi 2013; Azam, Khan 2016; Jeblia et al. 2016), and various crises (Esteve, Tamarit 2012) as the influential factors affecting GHG. Researchers testing the demographical factors used the population density, urbanisation areas as indicators strongly affected the level of GHG (Franklin, Ruth 2012; Liao, Cao 2013; Azam, Khan 2016).

The impact of business ethics on the development of human beings is a topic of various philosophic and economic discussions. Many studies deal with this link on the organizational level, while approach in this paper is new, since is done on the macro level. In that frame, there are plethora of studies dealing with the impact of ethical behaviour of individuals and their environmental and social attitudes on sustainably of organizations (Lapinskienè, Tvaronavičienė 2012; Potocan, Nedelko 2015). In this research, it is generally assumed that sustainable enterprises might help to lower the level of GHG and it is expected to have negative sign in estimation of the variable related to enterprises environment, social and governance (ESG) factor. To the best of our knowledge, it is one of the first attempt to empirically estimate the ethical level expressed through the lenses of sustainable enterprises to economic development.

The aim of this article is the evaluation of additional factors, besides keeping typical variables, the focus is on sustainable enterprises which might impact on the relationship between GHG and GDP based on the EKC approach in the chosen sample of EU countries.

The paper has the following structure. Sections 1 and 2 provide important theoretical and econometrical issues based on the considered concepts. Section 3 describes the main findings of the research. The last section summarizes the results, providing the concluding remarks, implications as well as defining possible areas for further research. 


\section{Literature review}

The EKC is a complex model both theoretically and empirically. The authors agree that the development trajectory for pollution is likely to reflect both market forces and changes in government regulation. The EKC concept first emerged in 1991 and in 1995 with Grossman and Krueger's pioneering study of the potential impacts of the NAFTA (North American Free Trade Agreement). Within the first wave of EKC studies, basic EKC models were used and income growth and its environmental impacts were estimated in the model without any explanatory variables. The latest studies combine the relationship between environmental pollution and economic growth and some other variables. Some studies support the EKC hypothesis, while others find a monotonically rising trend. The further empirical studies include some additional variables. In general articles can be divided into two groups based on main data analysis techniques. The first group comprises time series techniques for a single region or location (Fosten et al. 2012; Esteve, Tamarit 2012; Franklin, Ruth 2012; Azam, Khan 2016). The second group contains panel data techniques for the analysis of several regions (Tsurumi, Managi 2010; Wang et al. 2011; Hamit-Haggar 2012; Fujii, Managi 2013; Liao, Cao 2013; Boluk, Mert 2014).

In the first group, Fosten et al. (2012) considered the emissions of gases with respect to the environmental Kuznets curve relationship in the United Kingdom for the period from 1830 to 2003 for the $\mathrm{CO}_{2}$ and the $\mathrm{SO}_{2}$ models. The research showed that long-run results were in favour of the EKC hypothesis, with per capita $\mathrm{CO}_{2}$ and $\mathrm{SO}_{2}$ emissions, having an inverted-U relation with real GDP per capita. This suggests that mitigating of $\mathrm{CO}_{2}$ or greenhouse gas emissions and $\mathrm{SO}_{2}$ emissions will rely more on legislation than the reductions in economic growth. The researchers also used the gas price as the additional variable, which had partially explained the results. The authors suggested that the EKC model should be estimated by specifying and incorporating different measures of technological changes.

Esteve and Tamarit (2012) renewed the research for EKC evidence in Spain, using a linear integrated regression model with multiple structural changes. The authors used time-series data on the Spanish economy spanning from 1857 to 2007. They emphasized that the turning point in Spain was dated by 1986 and could be explained by the oil crisis of the 70s, caused by the political instability at the end of the Spanish dictatorship in 1975-1978, and by the shift in the energy mix that took place only at the beginning of the 80s. The coefficient of the relationship estimated between per-capita $\mathrm{CO}_{2}$ and per-capita income (or long-run elasticity) in the presented model showed a tendency to decrease over time. They found that the "income elasticity" coefficient with regard to $\mathrm{CO}_{2}$ was smaller than one. This implies that even if the shape of the EKC does not follow an inverted-U, it shows a decreasing growth path, pointing to a prospective turning point.

Franklin and Ruth (2012) contributed to time series studies, using the U.S. $\mathrm{CO}_{2}$ emissions in the additional explanation of the potential impact of population and the economic structure. The researchers used the log squared regression equation. The total 
$\mathrm{CO}_{2}$ emissions might continue to increase. The results suggested that there were some relevant relationships between the demography and the productive structure of the economy and $\mathrm{CO}_{2}$ emissions. The authors offered to choose the strategies that foster consumption choices consistent with those seen in a society with high elderly dependency ratios as they would more strongly guarantee the sustainable way.

Azam and Khan (2016) performed the empirical research based on annual time series data covering period 1975-2014. This study verified quantitatively the EKC hypothesis in the context of Tanzania (low income country), Guatemala (low middle income country), China (upper middle income country) and USA (high income country). Energy usage, trade openness and urbanisation growth rates were included in the model as additional factors affecting EKC. The results showed that $\mathrm{CO}_{2}$ emissions is positively related to energy consumption and trade openness in all four countries. Hence, authors concluded that each country should systemize energy consumption and formulate environment friendly trade policy at the national level to meet future demand and mitigate environment degradation in order to achieve the ultimate goal of sustainable economic growth and development.

In the second group of studies, Tsurumi and Managi (2010) examined the environmental Kuznets curve hypothesis for carbon dioxide, using generalized additive models with a generic flexible functional form, allowing a potentially non-linear non-monotonic relationship. A sample covered 30 OECD countries for the period 1960-2003. The results imply that economic growth was not sufficient to decrease $\mathrm{CO}_{2}$ emissions. The first group had a negative slope for the high-income levels, while the second group had a monotonically increasing trend at all income levels, and the third group displayed other trends or had confidence intervals which were too wide to interpret. Their results obtained by these authors suggested that economic growth is not sufficient to decrease $\mathrm{CO}_{2}$ emissions.

Wang et al. (2011) performed a panel data analysis of carbon dioxide emissions and economic growth in 138 countries in the period of 1971-2010. The chosen sample was divided into five quintiles according to the level of $\mathrm{CO}_{2}$ emissions in every country. In the process of increasing $\mathrm{CO}_{2}$ emissions quintiles, the growth of GDP would be higher than $\mathrm{CO}_{2}$ emissions, with income elasticity decreasing from more than one to below zero. The empirical results showed that the long-run relationship between the global carbon dioxide emissions and GDP was stable. The paper suggested that the top priority to mitigate global warming should be focusing on the countries with a high economic growth and a strong increase in carbon dioxide emission.

Hamit-Haggar (2012) performed the study, which analyses the causal relationship between greenhouse gas emissions, energy consumption and economic growth to a panel of Canadian industries over the period 1990-2007. These industries are responsible for about $56 \%$ of the total industrial greenhouse gas emitted in 2007 in Canada. The paper is more specifically to determine the nature of the long-run equilibrium and the causal relationship between greenhouse gas emissions, energy consumption and economic growth by taking into consideration the hypothesis of cross-section dependence. 
The results showed that, there is a strong evidence of a long-run relationship between greenhouse gas emissions and energy consumption. Within industries, almost all industries indicate that energy consumption has statistically significant impact on greenhouse gas emissions. Authors suggested that other factors not included in this model should be taken into account such as technology, taxes, trade, and so on.

Fujii and Managi (2013) assumed that $\mathrm{CO}_{2}$ emission for an entire country was unclear and did not show individual industrial characteristics or fuel choices. Following the ideas of economic scale, technology level and composition effects on the shape of the $\mathrm{EKC}$, the authors chose to estimate the EKC relationship separately, controlling these effects by the type of industry and type of fuel. They hypothesized that the EKC relationship between $\mathrm{CO}_{2}$ and growth would be possible for such industries as the wood, wood products and the paper, pulp and printing industries, which do not use fossil fuels as intermediate fuels and whose product value per weight is lower than that of the others. For other industries, referring, in particular, to steel and metal, which use coal as their main intermediate fuel, $\mathrm{CO}_{2}$ would increase proportionally with the production growth. They considered that the EKC relationship observed in the previous studies could be explained by industrial structural changes. It was found that overall $\mathrm{CO}_{2}$ emissions showed the $\mathrm{N}-$ shape trend. The EKC hypothesis was supported by the study of the industries of producing wood, wood products, paper and pulp, as well as printing and construction industries. $\mathrm{CO} 2$ emissions from coal and oil increased with economic growth in upstream industries. Hence, a conclusion was made that three industries were greener than the nine analysed with respect to $\mathrm{CO}_{2}$ emissions.

Liao and Cao (2013) examined the historical relationship between the economic development and carbon dioxide emission in 132 countries for the period of 1971-2009. They included in their empirical analysis such factors as urbanisation, population density, trade and energy mix. It was concluded, that while the economic development continued to drive up $\mathrm{CO}_{2}$ emission, urbanisation, population density, trade and energy mix would potentially contribute to the reduction of the absolute level of $\mathrm{CO}_{2}$ per capita emission. The authors noted that their results did not support the inverted-U shape concept, but rather described the trend observed in high income segments as a saturation of trend. As most of the countries are still below some threshold income per capita level, the economic policy mix, helping to foster green technology development and the additional $\mathrm{CO}_{2}$ emission reduction measures should be implemented to offset a negative stage of income and $\mathrm{CO}_{2}$ relationship. Otherwise, consistent with a historical trend, poorer countries will still need considerable emission volumes to outweigh their economic backwardness.

Boluk and Mert (2014) utilized panel data fixed effect analysis to examine the relationship between greenhouse gases, energy consumption (fossil energy and renewable energy) and GDP. The paper proposed and estimated a panel model for EU-16 over the period of 1990-2008. Estimated coefficients state that pollution increases with both fossil and renewable energy consumption. The fossil fuel consumption leads to a greater increase in pollution levels than renewable energy consumption. This implies that much more improvement in energy efficiency and/or, a shift in the energy mix towards less 
polluting energies (renewable energy technologies) could be very important in achieving environmental targets.

Despite the large number of empirical investigations made to date regarding the $\mathrm{EKC}$, the results are not conclusive. The corroboration of the ECK hypothesis also depends on the country sample showing the different empirical results between regions and countries, differences have been observed when considering, time-series or panel data characteristics.

The empirical investigations of factors, affecting GHG or $\mathrm{CO}_{2}$ as the main indicators referring climate change, shows that researcher used various indicators assessing the significance of special social - economic factors. These factors can be grouped in some areas: the prices of fuels (oil, gas, coal), various shocks (financial, political), sector structure (structure in production and consumption), demography (urbanisation, population density), trade openness, energy (usages, efficiency, type of fuel) and others (political system).

Based on theoretical studies, economic logic and available statistical variables for the chosen sample, following factors were estimated using the expanded EKC model: the share of a particular polluting industry, environmental taxes, energy taxes, R\&D, the dummy variable of the crises and the sustainability score.

\section{Model specification}

In this research, GHG represents a dependable variable of a country's environmental characteristics. In the EKC models, the GDP per capita has been taken as the variable capturing the activities and welfare of the particular state's citizens, which is assumed to affect the form of the EKC. GDP expressed in purchasing power parity is specifically used in this research for minimizing the potential differences in prices between the countries, which may arise at different stages of development. In this study it is assumed that the estimation of statistical significance of specific economic factors such as tax policy, the particular economic structure and R\&D expenditure can explain the height of EKC for the chosen sample. In addition, it is supposed that in Europe the leader in spreading ethical and social values in business countries may demonstrate a relationship between GHG and ESG variables. Three causes (the scale of economic activity, the structure of GDP, technological development referring as R\&D) has been chosen as the classical ones, in addition environmental taxes and energy taxes, referring to the policy options, and the enterprises' sustainability measured using ESG factors has been selected. The composition of economic activities influences the level of the environmental degradation as the consumption of resources and degradation intensity are different in different sectors of economy. It is assumed that improving technologies will lead to better environment without limiting general growth trends. In the context of sustainable development and green economy it is assumed that research and experimental development may be more related to environment friendly technologies and processes. Environmental and energy taxes is one of the factors affecting market mechanism forces playing out in EKC analysis and which can be actively managed by policy makers. Within ecological mod- 
ernisation the monitoring and making visible of environmental flows and qualities was believed to be one of the crucial processes for environmental reform. In order to fulfil the lack of qualitative data representing environment preferences in company level, in 2004 Bloomberg (2015) has introduced an index which can validate companies' activities in environmental, social and governance (ESG) pillars. Currently, ESG is employed to describe all the responsibilities of firms to their stakeholders, particularly, voluntary codes that exceed legislated requirements. The accounting data and external information have been taken from the Bloomberg platform (2015).

In this study the empirical validation has the aim to test the chosen additional factors, which might impact the relationship between GHG and GDP in the EU region. Five theoretical factors and proxy variables effecting EKC have been chosen for the analysis (Table 1).

In order to test the statistical significance of these variables, the classical reduced EKC equation has been expanded by additional variables. The selected theoretical model for

Table 1. Chosen theoretical factors and proxy variables referring a particular point effecting EKC

\begin{tabular}{|c|c|c|c|c|}
\hline \multicolumn{2}{|c|}{$\begin{array}{l}\text { Group } \\
\text { Theoretical factors }\end{array}$} & $\begin{array}{c}\text { Proxy } \\
\text { variables }\end{array}$ & Description of proxy variable & Expected sign \\
\hline \multirow[t]{3}{*}{$\begin{array}{l}\text { Classical } \\
\text { factors }\end{array}$} & $\begin{array}{l}\text { The scale of } \\
\text { economic } \\
\text { activity }\end{array}$ & $\begin{array}{l}\text { GDP per } \\
\text { capita }\end{array}$ & GDP in PPS (Euro per capita) & $\begin{array}{l}\text { Positive } \\
\text { or negative } \\
\text { (indicates } \\
\text { EKC form) }\end{array}$ \\
\hline & $\begin{array}{l}\text { The structure } \\
\text { of economy }\end{array}$ & $\begin{array}{l}\text { The share } \\
\text { of a particular } \\
\text { polluting } \\
\text { industry }\end{array}$ & $\begin{array}{l}\text { Agriculture, Production and } \\
\text { Construction sectors value added } \\
\text { as percentage of total GDP }\end{array}$ & Positive \\
\hline & $\begin{array}{l}\text { Technological } \\
\text { development }\end{array}$ & $\mathrm{R} \& \mathrm{D}$ & $\begin{array}{l}\text { Research and experimental } \\
\text { development include all } \\
\text { expenditures within the enterprise } \\
\text { business sector on the national } \\
\text { territory during a given period } \\
\text { and is shown as a percentage } \\
\text { of GDP }\end{array}$ & Negative \\
\hline \multirow{2}{*}{$\begin{array}{l}\text { Political- } \\
\text { governance } \\
\text { factors }\end{array}$} & \multirow{2}{*}{$\begin{array}{l}\text { Economic } \\
\text { and fiscal } \\
\text { instruments }\end{array}$} & $\begin{array}{l}\text { Environmental } \\
\text { taxes }\end{array}$ & $\begin{array}{l}\text { As percent of the total taxes and } \\
\text { social contributions }\end{array}$ & Negative \\
\hline & & Energy taxes & $\begin{array}{l}\text { Ratio of energy tax revenues } \\
\text { to final energy consumption } \\
\text { (Euro per tonne) }\end{array}$ & Negative \\
\hline $\begin{array}{l}\text { Socio- } \\
\text { demographical } \\
\text { factors }\end{array}$ & $\begin{array}{l}\text { Voluntary } \\
\text { activities }\end{array}$ & ESG score & $\begin{array}{l}\text { For any particular country ESG } \\
\text { disclosure score is calculated as } \\
\text { a Market Cap Weighted Average } \\
\text { of ESG disclosure score of } \\
\text { companies disclosing ESG data } \\
\text { listed in a county's exchange }\end{array}$ & Negative \\
\hline
\end{tabular}

Source: made by authors. 
this research is given below:

$$
\begin{aligned}
G H G_{i t}= & \alpha+\mu_{i}+\beta_{1} G D P_{i t}+\beta_{2} G D P_{i t}^{2}+\beta_{3} S E C T_{i t}+\beta_{4} R D_{i t}+\beta_{5} T A X_{i t}+ \\
& \beta_{6} \text { ENERTAX }_{i t}+\beta_{7} \text { ESGSORE }+ \text { CRISO8 } \\
i t & +\varepsilon_{i t},
\end{aligned}
$$

where:

$G H G_{i t}$ is a dependent variable for country $i$ in time $t$;

$G D P_{i t}$ is an independent variable for country $i$ in time $t$;

$S E C T_{i t}$ is an independent variable for country $i$ in time $t$;

$R D_{i t}$ is an independent variable for country $i$ in time $t$;

$T A X_{i t}$ is an independent variable for country $i$ in time $t$;

ENERTA $X_{i t}$ is an independent variable for country $i$ in time $t$;

$E S G S C O R E_{i t}$ is an independent variable for country $i$ in time $t$;

Cris $08_{i}$ is a dummy variable for country $i$ in 2008 in time $t$;

$\beta$ denotes the regression coefficients;

$\mu_{\mathrm{i}}$ is the cross-section specific effect;

$\varepsilon_{i \mathrm{t}}$ is an error term.

The study employs the equation form used by Holtz-Eakin and Selden (1995), Wang et al. (2011), He and Wang (2012), Fujii and Managi (2013), and Boluk and Mert (2014). The study follows the panel data analysis performed by Boluk and Mert (2014), and Lopez-Menendez et al. (2014).

\section{The empirical investigation}

The empirical study is based on the panel data; therefore, the econometric fixed effect panel data model is used for testing the hypothesis. The data sets for the analysis are chosen from Eurostat (2015) for the period 2006-2013. Only the countries with complete data sets were chosen for the analysis to avoid possible data gaps. In order to avoid potential distortions and/or very small beta coefficients in quadratic model estimation, the data for GHG and GDP were normalised to vary between 0 and 1, where the smallest value of the sample is equal to 0 , and the largest value is equal to 1 . At the same time, this facilitates the comparison of the results, as for example 0.5 equals to the average EU level. The variables, such as the share of a particular polluting industry, R\&D, environmental taxes, energy taxes, dummy variable for the first year of the financial crises and countries ESG factor were included in the model. The variables have been chosen based on the economic logic presented above and the available statistical data. The extended EKC analysis helps to verify if the selected variables have a statistically significant impact on the EKC relationship. The parameters of the model are in agreement with the theoretical econometric methodology. The results of the statistical analysis covering the whole period are presented in Table 2 and explained below.

For the panel model estimation, the Eviews software was used as an instrument to estimate the pooled EGLS (cross-section weight) method. The model was validated by the characteristics of the fitted model: $R^{2}$ and Adjusted $R^{2}$; P-values of Fisher and Student tests and residual analysis. As ESG concept is introduced only recently, and its statistical 
Table 2. Regression parameter estimates for the extended model

Dependent Variable: NNGGE_?

Method: Pooled EGLS (Cross-section weights)

Date: 08/08/16 Time: 14:12

Sample (adjusted): 20062013

Included observations: 8 after adjustments

Cross-sections included: 22

Total pool (balanced) observations: 176

Linear estimation after one-step weighting matrix

White cross-section standard errors \& covariance (no d.f. correction)

WARNING: estimated coefficient covariance matrix is of reduced rank

\begin{tabular}{|c|c|c|c|c|}
\hline Variable & Coefficient & Std. error & t-statistic & Prob. \\
\hline $\mathrm{C}$ & -0.183675 & 0.050529 & -3.635070 & 0.0004 \\
\hline NNGDP2_? & 1.158970 & 0.219755 & 5.273918 & 0.0000 \\
\hline NNGDP2_?^2 & -1.002812 & 0.277191 & -3.617761 & 0.0004 \\
\hline TAX1_? & 0.087480 & 0.012477 & 7.011110 & 0.0000 \\
\hline ENERGTAX_? & -0.000860 & $9.43 \mathrm{E}-05$ & -9.114809 & 0.0000 \\
\hline ESGSCORE_? & -0.000373 & $9.42 \mathrm{E}-05$ & -3.963977 & 0.0001 \\
\hline SECT_? & 0.008955 & 0.000774 & 11.57391 & 0.0000 \\
\hline CRIS08 & -0.004869 & 0.001077 & -4.519146 & 0.0000 \\
\hline RD_? & $-9.84 \mathrm{E}-05$ & $2.43 \mathrm{E}-05$ & -4.051752 & 0.0001 \\
\hline \multicolumn{5}{|l|}{ Fixed Effects (Cross) } \\
\hline LITHUANIA--C & -0.139171 & & & \\
\hline LATVIA--C & -0.130984 & & & \\
\hline ESTONIA--C & 0.067978 & & & \\
\hline GREECE--C & 0.159457 & & & \\
\hline SPAIN--C & -0.024036 & & & \\
\hline ITALY--C & 0.014589 & & & \\
\hline PORTUGAL--C & -0.051318 & & & \\
\hline DENMARK--C & 0.149012 & & & \\
\hline BELGIUM--C & 0.084539 & & & \\
\hline FRANCE--C & 0.043074 & & & \\
\hline GERMANY--C & 0.117103 & & & \\
\hline NETHERLANDS--C & 0.066779 & & & \\
\hline AUSTRIA--C & -0.027568 & & & \\
\hline SWEDEN--C & -0.205931 & & & \\
\hline $\mathrm{UK}-\mathrm{C}$ & 0.098447 & & & \\
\hline IRELAND - C & 0.177090 & & & \\
\hline POLAND $-\mathrm{C}$ & 0.008149 & & & \\
\hline SLOVAKIA-C & -0.098704 & & & \\
\hline SLOVENIA-C & -0.154102 & & & \\
\hline
\end{tabular}


End of Table 2

\begin{tabular}{|c|c|c|c|}
\hline Variable & Coefficient & Std. error & Prob. \\
\hline HUNGARY - C & -0.109754 & & \\
\hline FINLAND-C & -0.114433 & & \\
\hline \multirow[t]{2}{*}{ CZECH_REPUBLIC-C } & 0.069785 & & \\
\hline & Effects & fication & \\
\hline \multicolumn{4}{|c|}{ Cross-section fixed (dummy variables) } \\
\hline \multicolumn{4}{|c|}{ Weighted statistics } \\
\hline R-squared & 0.991158 & Mean dependent var & 0.650422 \\
\hline Adjusted R-squared & 0.989401 & S.D. dependent var & 0.493675 \\
\hline S.E. of regression & 0.026986 & Sum squared resid & 0.106328 \\
\hline F-statistic & 564.3328 & Durbin-Watson stat & 1.651543 \\
\hline $\operatorname{Prob}(\mathrm{F}-$ statistic $)$ & 0.000000 & & \\
\hline \multicolumn{4}{|c|}{ Unweighted statistics } \\
\hline R-squared & 0.949496 & Mean dependent var & 0.294089 \\
\hline Sum squared resid & 0.139116 & Durbin-Watson stat & 1.008478 \\
\hline
\end{tabular}

estimation is available only starting from 2006 year, therefore some of analysed model's statistical characteristics should be taken with care duo to short estimation time span. When the P-value is lower than 0.05 , it indicates that this coefficient has a statistically significant explanatory power with the probability of $95 \%$. The model was validated by the characteristics of the fitted model. $R^{2}$ is 0.991 , and Adjusted $R^{2}$ is $0.989 . R^{2}$ is very high due to its estimation specific for pooled data series. The P-value of Student's test provided in the column "Prob" was used to determine the statistical significance of the estimated coefficients of the proxy variables. F-statistics of the final extended quadratic model is 564.3328 and probability of $\mathrm{F}$-statistics being zero is non-existent. In this case, Durbin-Watson stat is 1.652, indicating a substantial serial correlation of the residuals due to short analysis time span.

Summing up the results of the estimation coefficients, several conclusions could be made. First, based on mathematical logic, the expanded model may not always show the existence of the EKC form because additional variables change the form of a function. However, the signs of the coefficients by GDP $>0$ and $\mathrm{GDP}^{2}<0$ indicate that it could be a form of the inverted-U. Second, the existence of differences between the pollution levels, i.e. the height of EKC, not captured by the factors analysed, in different countries in the model is demonstrated by the differences between a country's intercepts. Third, in general, it can be seen in Table 2 that the considered indicators produce a statistically significant effect.

The existence of differences between pollution levels in different countries not explained by the analysed variables is demonstrated by the remaining differences between a country's intercepts (i.e. the height of EKC). The higher is the intercept of a country, the higher is the unadjusted GHG level. As a general case, countries having a higher de- 
velopment level tend to have a higher EKC (Denmark, Ireland), while less developed countries have a lower EKC (Latvia, Lithuania). The applied EKC estimation method allows evaluating the specific effect of a variable not only on the form but also on the height of EKC (having other effects fixed).

It was expected to get a positive sign of the economic structure, and it had been obtained. Optimisation of the structure of the three industries needed a long development process. Appropriate reduction in the proportion of highly polluting sectors and the development of the service sector, high-tech sector and other tertiary industries may reduce the pollution emission. This conclusion is in line with the conclusions of Baodong and Xiaokun (2011), He and Wang (2012).

The traditional EKC theory pointed out that the technological effect is one of the factors, which drive the declining part of EKC throughout the entire period of economic development. Many researchers highlighted potential problems related to the correct estimation of R\&D proxy due to differences in specific countries and an unknown time lag of the R\&D impact; nevertheless, the same direction was proved by Auffhammer et al. (2008) and Yin et al. (2015).

An effective measure used in the environmental policy is associated with the environmental taxes. However, the result is not straightforward: the regression coefficient of the taxes has an expected negative sign, but the environmental taxes do not have the expected impact, since the coefficient of the environmental taxes has a positive sign in the model, implying that higher taxes result in a higher GHG level. This may be explained by the fact that the category of overall environmental taxes is too broad, and not necessarily directed to regulate the level of GHG.

The increase of energy taxes affects the decrease of the level of GHG, this relationship is more direct than overall environmental taxes and it is an easy way to explain. The results obtained show that their growth helps to reduce the level of GHG and is in line with Boluk and Mert (2014). As useful welfare policies, environmental regulations can control pollution overall and thus produce similar joint action on controlling the GHG emissions, but it may generate environmental inequities.

The regression coefficients next to variables referring to the global financial crisis have a negative sign, which means that during these crises, short-term changes in economic relationships decreased the GHG level even more than indicated by the slowing economic growth. It confirms a conclusion that the level of GHG could be impacted by unexpected shocks.

The regression coefficients next to ESG score have a negative sign, which means that a higher number of enterprises implementing ESG practices lead to lower a level of GHG in a country. This short ESG policy analysis shows that corporations implementing ESG practices have statistically significant impact on the height of the EKC curve. Deeper discussions and analysis in this area should be of interest for further research. 


\section{Conclusions}

The estimation of the effects produced on GHG by the economic growth and related various external factors can be viewed as a tool supporting a country's strategic decision. In this paper, the expanded EKC model estimating the relationship between GHG and GDP and some additional factors (e.g. the share of a particular polluting industry, $R \& D$, environmental taxes, energy taxes, the dummy variables representing year of the crises as well as the estimation of country's enterprises sustainability) is tested empirically for the twenty EU countries. In order to test the effects of different factors in the European Union countries, the estimation was made by the fixed effect panel model. In general, the research confirmed the presence of the inverted-U relationship. Hence, countries having a higher development level tend to be on the higher phase of EKC (Denmark, Ireland) and already showing decreasing trends, while countries which are less developed are on the lower phase EKC, but showing increasing trend (Latvia, Lithuania). The empirical expanded EKC model estimation suggests that the analysed factors are relevant for the management of climate change as they demonstrate a statistically significant effect on the dynamics of GHG, however, the direction determined by estimating one variable (environmental taxes) does not correspond to economic logic. The size of agriculture, production and construction has a positive sign and therefore negatively affects the level of GHG. The variable of R\&D, energy taxes, the dummy variables representing the year of financial crises as well as the number of enterprise sustainability have a negative sign, which means that a higher value of these indicators is associated with a lower level of GHG.

The following new results in the field of economics have been obtained in the present investigation - a model integrating the main factors influencing the emissions of the GHG, which is suitable for modelling the trends of EKC development, has been created and empirically tested. In addition to classical factors: sectorial structure, environmental taxes, energy taxes, research and experimental development expenditure a new factor reflecting business sustainability was analysed.

In terms of practical implications this paper is useful for policy adjustments on the national level in order to enhance sustainability of organizations, due to the positive impact of higher level of sustainability on reducing GHG. The empirical investigation has revealed that the chosen variable representing companies working in any country sustainability could have positive effect on countries environmental indicators. Hence, in this context, it is assumed that environmental incentives, comprising various states' policy tools and voluntary activities, should lead to better environmental quality and competitiveness, at the same time.

The paper has some limitations. First, the concept of ESG and, specifically, its quantitative evaluation are still completely new, and there is no consensus on the methods of its estimation, which can reduce the power of the analysis and/or conclusions. Second, some countries were not included due to the missing data.

The avenues for future research might be extended into some other areas: using the proposed technique, other environmental variables could be tested, going beyond the scope of "voluntarily activities of ESG", another direction of studies may be related to the deeper analysis of the indicators referring the way of country or company sustainability in the framework of the EKC. 


\section{References}

Alam, M.; Murad, W.; Wahid, M.; Noman, A. H.; Ozturk, I. 2016. Relationships among carbon emissions, economic growth, energy consumption and population growth: testing Environmental Kuznets Curve hypothesis for Brazil, China, India and Indonesia, Ecological Indicators 70: 466-479. https://doi.org/10.1016/j.ecolind.2016.06.043

Auffhammer, M.; Richard, T.; Carson, R. 2008. Forecasting the path of China's $\mathrm{CO}_{2}$ emissions using province-level information, Environmental Economics and Management 55(3): 229-247. https://doi:10.1016/j.jeem.2007.10.002

Azam, M.; Khan, A. 2016. Testing the Environmental Kuznets Curve hypothesis: a comparative empirical study for low, lower middle, upper middle and high income countries, Renewable and Sustainable Energy Reviews 63: 556-567. https://doi.org/10.1016/j.rser.2016.05.052

Baodong, L.; Xiaokun, W. 2011. Economic structure and intensity influence air pollution model, Energy Procedia 5: 803-807. https://doi:10.1016/j.egypro.2011.03.141

Boluk, G.; Mert, M. 2014. Fossil \& renewable energy consumption, GHGs (greenhouse gases) and economic growth: evidence from a panel of EU countries, Energy 74(1): 439-446.

https://doi.org/10.1016/j.energy.2014.07.008

Bloomberg platform. 2015. [online], [cited 1510 2015]. Available from Internet: https://www. bloomberg.com/professional/

Esteve, V.; Tamarit, C. 2012. Is there an environmental Kuznets curve for Spain? Fresh evidence from old data, Economic Modelling 29(6): 2696-2703.

https://doi.org/10.1016/j.econmod.2012.08.016

Eurostat. 2015. [online], [cited 1011 2015]. Available from Internet: http://epp.eurostat.ec.europa.eu/

Fosten, J.; Morley, B.; Taylor, T. 2012. Dynamic misspecification in the environmental Kuznets curve: evidence from $\mathrm{CO} 2$ and $\mathrm{SO} 2$ emissions in the United Kingdom, Ecological Economics 76: 25-33. https://doi:10.1016/j.ecolecon.2012.01.023

Franklin, R. S.; Ruth, M. 2012. Growing up and cleaning up: the environmental Kuznets curve, Applied Geography 32: 29-39. https://doi:10.1016/j.apgeog.2010.10.014

Fujii, H.; Managi, S. 2013. Which industry is greener? An empirical study of nine industries in OECD countries, Energy Policy 57: 381-388. https://doi.org/10.1016/j.enpol.2013.02.011

Grossman, G. M.; Krueger, A. B. 1991. Environmental impact of a North American free trade agreement. Working Paper 3194. Cambridge, MA: National Bureau of Economic Research.

Grossman, G. M.; Krueger, A. B. 1995. Economic growth and the environment, Quarterly Journal of Economics 110: 353-377. https://doi.org/10.2307/2118443

Hamit-Haggar, M. 2012. Greenhouse gas emissions, energy consumption and economic growth: a panel cointegration analysis from Canadian industrial sector perspective, Energy Economics 34(1): 358-364. https://doi:10.1016/j.eneco.2011.06.005

He, J.; Wang, H. 2012. Economic structure, development policy and environmental quality: an empirical analysis of environmental Kuznets curves with Chinese municipal data, Ecological Economics 76: 49-59. https://doi:10.1016/j.ecolecon.2012.01.014

Holtz-Eakin, D.; Selden, T. M. 1995. Stoking the fires? $\mathrm{CO}_{2}$ emissions and economic growth, Journal of Public Economics 57: 85-101. https://doi.org/10.1016/0047-2727(94)01449-X

Jeblia, M. B.; Slim, S. B.; Ozturk, I. 2016. Testing environmental Kuznets curve hypothesis: the role of renewable and non-renewable energy consumption and trade in OECD countries, Ecological Indicators 60: 824-831. https://doi.org/10.1016/j.ecolind.2015.08.031

Lapinskiené, G.; Tvaronavičienè, M. 2012. Environmental, social and governance performance of companies: the empirical research on their willingness to disclose information, in The 7th International Scientific Conference Business and Management, 10-11 May 2012, Vilnius, Lithuania. 
Lapinskienè, G.; Tvaronavičienė, M.; Vaitkus, P. 2013. Analysis of the validity of environmental Kuznets curve for the Baltic States, Environmental and Climate Technologies 12: 41-46. https://doi:10.2478/rtuect-2013-0015

Lapinskienè, G.; Tvaronavičienè, M.; Vaitkus, P. 2014. The emissions of greenhouse gases and economic growth - the evidence of the presence of the environmental Kuznets curve in the European Union countries, Technological and Economic Development of Economy 20(1): 65-78. https://doi:10.3846/20294913.2014.881434

Liao, H.; Cao, H. 2013. How does carbon dioxide emission change with the economic development? Statistical experiences from 132 countries, Global Environmental Change 5: 1073-1082. https://doi.org/10.1016/j.gloenvcha.2013.06.006

Lopez-Menendez, A. J.; Perez, R.; Moreno, B. 2014. Environmental costs and renewable energy: re-visiting the environmental Kuznets curve, Environmental Management 145: 368-373.

https://doi:10.1016/j.jenvman.2014.07.017

Meadows, D.; Randers, J.; Meadows, D. 2004. Limits to growth: the 30-year update. USA, Chelsea: Green Publishing Company.

Meadows, D. H.; Meadows, D. L.; Randers, J.; Behrens, W. 1972. Limits to growth: a report for the Club of Rome's Project on the predicament of mankind. New York: Universe Books.

Potocan, V.; Nedelko, Z. 2015. A new socio-economic order: evidence about employees' values' influence on corporate social responsibility, Systems Research and Behavioural Science 32(2): 230-239. https://doi.org/10.1002/sres.2264

Randers, J. 2012. A global forecast for the next forty years 2052. Vermont: Chelsea green publishing white river junction.

Rodríguez, M.; Pena-Boquete, Y.; Pardo-Fernandez, J. C. 2016. Revisiting Environmental Kuznets curves through the energy price lens, Energy Policy 95: 32-41.

https://doi.org/10.1016/j.enpol.2016.04.038

Shafik, N.; Bandyopadhyay, S. 1992. Economic growth and environment quality: time series and cross-country evidence. Background Paper for the World Development Report. The World Bank, Washington DC.

Tsurumi, T.; Managi, S. 2010. Decomposition of the environmental Kuznets curve: scale, technique, and composition effects, Environmental Economics and Policy Studies 11: 19-36.

https://doi:10.1007/s10018-009-0159-4

Wang, S.; Zhou, D. Q.; Zhou, P.; Wang, Q. 2011. $\mathrm{CO}_{2}$ emissions, energy consumption and economic growth in China: a panel data analysis, Energy Policy 39: 4870-4875.

https://doi:10.1016/j.enpol.2011.06.032

Yin, J.; Zheng, M.; Chen, J. 2015. The effects of environmental regulation and technical progress on CO2 Kuznets curve: an evidence from China, Energy Policy 77: 97-108.

https://doi:10.1016/j.enpol.2014.11.008

Giedrė LAPINSKIENĖ. Lecturer, PhD in Social Sciences (economics) at the Department of Enterprise Economics and Management, VGTU. Research interests: sustainable development, environmental economics, green economy.

Kęstutis PELECKIS. Professor, PhD in Social Sciences (economics) at the Department of Enterprise Economics and Management, VGTU. The author of more than 100 publications. Research interests: economic growth, sustainable development, increase in the efficiency of business meetings and negotiations.

Zlatko NEDELKO. Assistant Professor, PhD in Social Sciences (business) at the University of Maribor, Faculty of Economics and Business, Department of Management and Organization. Research interests: management, organization, business ethics, personal values, corporate social responsibility, transitional issues and innovativeness. 